\title{
Letizia Paoli, Victoria A. Greenfield and Peter Reuter: The World Heroin Market: Can Supply Be Cut?
}

\author{
Studies in Crime and Public Policy, Oxford University Press, \\ New York, 2009, 392 pages, US\$35.00 (Hardcover), \\ ISBN: 978-0-195-32299-6
}

\section{Dan Ciccarone}

Received: 9 March 2010 / Accepted: 11 March 2010 /

Published online: 30 March 2010

(C) The Author(s) 2010. This article is published with open access at Springerlink.com

Supply shocks in the global heroin market, e.g., the Taliban ban, and Australian 'drought,' have amplified interest in global heroin flows. In The World Heroin Market, authors Paoli, Greenfield and Reuter respond to these events with a research question: 'Can world heroin production, and more generally, opium supply be reduced, and with what consequences?' Their aim is to explore this question by examining markets' sizes, participants and their interactions, responses to change, and in turn, answer another question: 'Is the world opiate market unified or segmented?' The World Heroin Market is a clear-sighted and accessible reference for those trying to understand the international heroin trade and its effects on countries. The book reflects the disciplinary strengths of the author triad; this integration of criminology, economics, and public policy creates a substantial contribution to the literature that should be of strong interest to scholars and practitioners in public policy, criminal justice, economics, and public health.

This is a complex and detailed book. Part one (chapters 2-5) covers: the historical development of the global opiate market and international policies to control it (chapter 2); an overview of the contemporary market including sources, trade routes and consumption (chapter 3); details on the effects of the Taliban-induced Afghanistan opium embargo (chapter 4); and the authors' unified 'flow model' (chapter 5). The chapters in part two (69), consist of 'Country Studies' exploring the detailed market conditions in the major producing and trafficking countries of Afghanistan, Burma, India, Colombia, and Tajikistan. Second tier producing/trafficking countries are covered in appendix D. The third part of this book includes a theoretical exploration of govermentality and three levels of effective illegality in determining the size and organization of regional opiate markets (chapter 10). The book is capped with a chapter on synthesis of findings and policy implications (Chapter 11). A suggested approach to reading the book is offered. Chapter 2 provides historical background while chapters 3, 4, and 5 are the 'analytical heart' of the book. The 'Country Studies' section is meant for regional studies and drug market scholars

D. Ciccarone $(\square)$

Department of Family and Community Medicine, Department of Anthropology, History and Social Medicine, University of California, 500 Parnassus, MU-3E, Box 0900, San Francisco, CA 94143, USA e-mail: ciccaron@fcm.ucsf.edu 
and experts. The govermentality and policy chapters (10 and 11) are considered an essential read. Three appendices provide detail on legal opium production (A), methodological issues in estimating consumption (B), and an empiric use of the 'flow' model in estimating drug market income in GDP-like terms in Central Asia (C).

What separates this book from prior works is its systematic gathering and analyzing of global heroin market data, and drawing of policy relevant conclusions across regions. The authors' empiric model is called a 'flow model' which, based on an accounting framework, imposes consistency to the data (even if only estimates) of production, seizures, and consumption. The flow model allows for a more complex understanding of the world opiate market and reveals some key insights. It demonstrates Asia's dominance as an opiate producer ( $80 \%$ of opium production is in Afghanistan), confiscator (two-thirds of seizures are in Asia), and consumer (two-thirds in Asia). Tajikistan has quickly become a key transit point for Afghan opiates feeding Russia's growing appetite for heroin. Inventories cushion supply shocks, e.g., the Taliban ban. Data shortcomings are the major challenge and there is lots of honesty and clarity about the assumptions used in filling data gaps.

The authors' theoretical model is called 'varying illegality,' which examines enforcement at three levels, none, lax, and strict, and the market dynamics which operate under each of these respective paradigms. Key findings include the effects of varying effective illegality on drug organization size, participant behaviors, and on local/regional societies. The authors remind us that strict enforcement may reduce opiate market-related violence, corruption, and instability, but that it cannot occur in isolation and transitionally without negative consequences on local peoples. Long-lasting reductions in opiate supply occur predominately as a result of long-term economic development and political stability.

The policy implications of this work are numerous and humbling. To be sure, the authors are pessimistic: the growth of consumption in Russia, production in Colombia, and trafficking in Tajikistan all point out that 'changes for the worse can happen with tremendous rapidity and magnitude, rarely matched by changes for the better.' Industry relocation (aka the 'balloon effect') is likely with strong single focused prohibition efforts. Suggestions to convert illicit producers to licit may be problematic given the authors' analysis of India's licit opiate diversion (making it the third largest illicit supplier!) There is a silver lining: lasting national or regional reductions are possible given a long-term perspective with institution building and economic development supported by sustained international effort. Policy opportunities suggested by the authors' analysis include targeted interventions in regions exhibiting strong producer to retail market chains, what the authors call 'segmented markets.' There is also discussion of some unorthodox proposals, including: broader inclusion of perspectives in policy debates, e.g., NGOs with experience in opium-growing regions and with drug users should be in the loop in drug policy formulation and implementation; and increased flexibility of global conventions to allow more regional and within country policy solutions, e.g., heroin maintenance programs in Europe, which may reduce the consequences of strictly prohibitionist policies on users.

This book has a few limitations. Let's start with the question of market segmentation, which is taken up in several places. Data are presented that strongly suggest segmentation has occurred, yet the title and much of the language in the book seems bent toward the unified global market theory. Segmentation, over the past two decades, is supported by analyses of farm gate prices, seizures, and chemical composition. Market segments include the Americas (Colombian and Mexico to the US), Southwest Asia to Europe, and Southeast Asia to Australia. The Taliban cutback - which affected opiate flows to Europe - had no effect on US prices, or in markets supplied by Burmese production, i.e., China and India. The Australian heroin 'drought' appears to be due to a unique regional supply shock. In 
addition, the authors are not entirely convincing on the reasons for market segmentation: they state international prohibition honing down the size and sophistication of opiate producers and kinship ties leading to durable regional trafficking. These are sound arguments. A countervailing argument (that is not entirely incompatible) is that market forces themselves are shaping regional markets with regional sources outcompeting distant sources for a given market share. Evidence for the latter exists in the US-Americas market. Also missing is consideration of increased international flows of licit goods and services, i.e., globalization, through free trade agreements, etc., affecting illicit drugs' routes and flows.

My own research, focusing on the US market and its suppliers, supports segmentation (which I term exclusive markets) (Ciccarone 2005; Ciccarone et al. 2009), global supply gluts (Ciccarone 2005; Ciccarone et al. 2009), and differential health effects based on heroin type (Ciccarone 2009). My analysis of US Drug Enforcement Administration (DEA) retail level data counters these authors' inference from their flow model predicting continuing substantial importation of Asian heroin. The US-Americas market is not characterized in as much detail as, e.g., the European-Southwest Asian market. For example, the reasons for Colombia's de novo entry into the heroin market are incomplete; mentioned are consolidation of smuggling networks servicing the US market, internal semi-autonomous regions, and central government weakness. A richer discussion might include: structural adjustment policies in Bolivia and Peru; the collapse of the cocaine cartels and the resulting fragmentation of producers; preferential crop eradication efforts; and not least of which, increasing market efficiencies including the effects of North American free trade agreements (Ciccarone et al. 2009).

Paying attention to heroin type/source helps public health as well as supplyside policies. Heroin type is strongly associated with source (identifiable through chemical signature) and source may correlate with public health outcomes, e.g., HIV (Ciccarone and Bourgois 2003) and bacterial infections (Ciccarone 2009). One of the only complete stumbles of this book is its suggestion that Colombian heroin was deliberately refined into heroin HCL (powder) to avoid competition with Mexican producers (there is no evidence of competition, only of cooperation) and to take advantage of HIV prevention practices (assuming users would snort it). On the contrary, Mexican 'black tar' heroin is the form correlated with reduced HIV (Ciccarone and Bourgois 2003), and the major route for using Colombian powder is through injection.

This is an insightful tome on the world heroin trade; one that will be immensely useful to those concerned about the continued facile flows of global heroin. I look forward to rereading and thumbing through this book for years to come. I also look forward the sequel: World Heroin Market: Can Demand (or Harms) Be Reduced?

Open Access This article is distributed under the terms of the Creative Commons Attribution Noncommercial License which permits any noncommercial use, distribution, and reproduction in any medium, provided the original author(s) and source are credited.

\section{References}

Ciccarone, D. (2005). The political economy of heroin: regional markets, practices and consequences (Lead Editorial). International Journal of Drug Policy, 16(5), 289-290.

Ciccarone, D. (2009). Heroin in brown, black and white: structural factors and medical consequences in the US heroin market. International Journal of Drug Policy, 20(3), 277-282.

Ciccarone, D., \& Bourgois, P. (2003). Explaining the geographical variation of HIV among injection drug users in the United States. Substance Use \& Misuse, 38(14), 2049-2063.

Ciccarone, D., Kraus, A., \& Unick, J. (2009). Impact of South American heroin on the US heroin market 1993-2004. International Journal of Drug Policy, 20(5), 392-401. 